\title{
Effects of Selective Contracting with Positive Incentives on the Choices of Dutch Consumers for Health Care Options: Results of an Experiment
}

\author{
Floris-Willem Enzerink, Christiaan Lako \\ Department of Public Administration, IMR, Radboud University, Nijmegen, The Netherlands \\ Email:c.lako@fm.ru.nl
}

Received 3 May 2016; accepted 4 June 2016; published 8 June 2016

Copyright (C) 2016 by authors and Scientific Research Publishing Inc. This work is licensed under the Creative Commons Attribution International License (CC BY). http://creativecommons.org/licenses/by/4.0/

(c) (i) Open Access

\section{Abstract}

Since the introduction of the Health Insurance Act in the Netherlands in 2006, insurers are incentivized to compete on price for basic health insurance, and on price and quality for supplementary insurance. It is possible for health insurers to implement a differentiated deductible since the first of January 2009. This paper describes an experiment. It is designed to study this differentiated deductible as a financial policy instrument. It focuses on the effect of selective contracting with positive incentives on the choice-behaviour of the insured. The goal of this study is to gain insight in the working mechanism of this financial policy instrument that is meant to reduce healthcare costs. The study is designed as a vignette study. The vignettes are presented in pairs of two to the respondents. The vignettes contain various elements including premium costs, deductible, degree of selective contracting and availability of quality-information (CQI). As the respondents in the design of this choice experiment have to choose between confronting health plans, it is understandable that they value these policies on their characteristics (so-called attributes). Subsequently, a statement can be formulated on the relative value assigned to these attributes by the respondents, clearly preferring one health plan over the other. Finally 99 respondents were included in our study. Logistic regression analysis was performed. This study shows that the deductible as choice-influencing instrument has less influence as age increases. The proclaimed cost savings of this deductible might be lower than expected. Generally, it can be concluded that healthier people are less likely to choose the extensive health plan. However, this effect reverses when the most extensive and less extensive are presented to the participants. The results thus show a clear demarcation in the preferences of consumers. A similar demarcation also has been found in the data concerning travel distance. When contracted care is within $\mathbf{3 0}$ minutes, this health plan is preferred over the more extensive and expensive one. However, this study also shows that this effect reverses when the travel distance increases to 45 minutes. Consumers in this situation are reluc- 
tant to choose selective care and choose for the extensive and expensive option. Premium costs have a negative effect. A health plan becomes less attractive when the price increases. In addition, an increase in the availability of CQI makes a health plan more attractive. It can be concluded from this study that the deductible as choice-influencing instrument seems to work for young and healthy people, provided that they do not have to travel more that 30 minutes.

\section{Keywords}

\section{Differentiated Deductible, Experiment, Health Plan}

\section{Introduction}

The use of a differentiated deductible is believed to be an effective instrument in the reduction of the increasing health care expenditures in the Netherlands [1]. Health care expenditures have risen from $€ 46.9$ billion (11.2\% of the GDP) in the year 2000 to $€ 94.2$ billion (15.6\% of the GDP) in 2013 [2].

Scholars argue that this trend can be attributed to a combination of the greying of the Dutch population, an increase in technology and medication, higher prosperity (c.f. affluence-related diseases) and the care system as a whole that is not designed to reduce expenditure [3]-[5]. In addition, as the health sector is labour-intensive, salary-increase is according to the Baumol-effect not accompanied with an increase in productivity [5]. With the increasing health care expenditures in the Netherlands, the costs of health insurances will also rise. Van Wijnmalen [4] suggests that this will mean an increase in the deductible and premium costs. The deductible has indeed risen from $€ 155$ in 2009 to $€ 385$ in 2016 (an increase of 148.4\%). In addition, the premium costs rose from an average of $€ 1.150$ to $€ 1.211$ in 2015 (an increase of 5.3\%).

With the introduction of the Dutch Healthcare act of 2006 (Zorgverzekeringswet) a system of selective contracting was introduced. This entails the insurance companies buying healthcare from the healthcare providers at an optimal price-performance ratio. Health insurers have to negotiate and provide the eligible providers with a contract [6]. Dutch citizens are expected to "vote with their feet" [7]. Assumptions of this hypothesis are the absence of transaction costs, the access of patients to full information and the absence of external effects

This experiment is designed to study the differentiated deductible as a financial policy instrument. It focuses on the effect of selective contracting with positive incentives on the choice-behaviour of the insured. The goal of this study is to gain insight in the working mechanism of this financial policy instrument that is meant to reduce healthcare costs. In order to judge its efficiency and effectiveness and provide recommendations, a choice experiment is conducted.

The experiment is a replication of the study of Van Wijnmalen [4] and based on a theoretical framework related to the Behavioural Model of Health and Illness by Anderson and Bartkus [8] (cited by van Wijnmalen [4]).

This framework provides an overview of the factors that influence the choice-behaviour of the insured. The authors make a distinction among supply-, demand- and context-related factors. The supply-side covers the characteristics of insurance companies and the providers. Theories on, for instance, selective contracting, competition, premium costs, deductibles and quality information were reviewed. The demand-side entails the features of the insured including risk aversion and demographics. Context-related factors include, for instance, travel distance.

\subsection{Supply-Side Factors}

Selective contracting is a concept that is implemented widespread in the United States under the title "Preferred Provider Organizations" (PPO's). It entails a cooperation (in a contract) between care providers and insurance organisations. According to this contract, providers deliver healthcare to the insured that benefit from choosing PPO-care. This system was constructed to manage the rising costs of health care [9]. PPO's are claimed to provide in efficient healthcare. This results in an increase in quality and a reduction of costs. This cost-reduction would increase access to healthcare. Howard [10] shows in his study of kidney-transplantation treatments that patients using contracted healthcare have higher survival rates. On the other hand, there are also studies that do not resemble these positive effects (see for instance Miller \& Luft [11]). So, evidence is mixed. 
Research shows that it is essential to have competition between healthcare providers to reduce costs with selective contracting [12].

The number of Dutch health insurers has decreased as a result of mergers and takeovers. Currently four major insurers dominate $90 \%$ of the healthcare market in the Netherlands [13].

Everyone working or living in the Netherlands is obliged to pay premium costs for the basic plan ("basispakket”). Premium costs of the same basic plan differ for each insurer. There are also supplementary policies [6].

Some studies suggest that premium costs are decisive in the choice of a health insurer [14]. This might entail several risks. When too much emphasis is paid to competition on premium costs, less attention might be paid to quality. Other studies do not show the premium costs as the most decisive factor in the choice of a health plan.

It is possible for health insurers to implement a differentiated deductible since the first of January 2009 [1]. This should be done by referring insured to contracted healthcare providers. When a patient uses the contracted care, no deductible is asked from him or her. The deductible can be seen as a positive incentive to choose contracted care. Ever since, only half of the insurance policies in the Netherlands use this kind of positive incentive.

A study of Boonen, Laske-Aldershof \& Schut [15] shows that when quality information (CQI) is publicly available, the insured are much more likely to switch health plans.

\subsection{Demand-Side Factors}

The literature is not consistent regarding demographic factors like age and gender.

Research [16] shows an inverse relationship between the deductible and the willingness to switch health plans. People with a higher deductible are less willing to switch health plans. This indicates that risk-aversive patients are not content with a suboptimal health insurance plan. This also erodes the idea of a rational choice when it comes to choosing a health plan.

\subsection{Context-Related Factors}

Research shows that people prefer going to a nearby hospital. Empirical data shows, however, that in the Netherlands $99 \%$ the citizens live in a 30-minute vicinity of a hospital and $69 \%$ of the Dutch have three hospitals within the same travel distance [17]. Distance therefore may have a limited effect in the Netherlands.

\section{Methods}

This study is designed as a vignette-study. It is used for a study of reported behaviour [18]. The vignettes are presented in pairs of two to the respondents. The vignettes contain various elements including premium costs, deductible, degree of selective contracting and availability of quality-information (CQI). Table 1 shows the vignettes.

As the respondents in the design of this choice experiment have to choose between confronting health plans, it is understandable that they value these policies on their characteristics (so-called attributes). Subsequently, a statement can be formulated on the relative value assigned to these attributes by the respondents, clearly preferring one health plan over the other.

The website thesistools.com was used for the data-collection. This is an online platform to conduct enquiries

Table 1. Summary of the vignettes in the choice experiment.

\begin{tabular}{|c|c|c|c|}
\hline \multirow{2}{*}{ Element } & \multicolumn{3}{|c|}{ Vignettes } \\
\hline & Choice A & Choice B & Choice C \\
\hline Premium & $€ 120 /$ month (€1.440/year) & $€ 100 /$ month (€1.200/year) & €80/month (€960/year) \\
\hline Deductible & $€ 375$ & $€ 0$ (in case of contracted care) & $€ 0$ (in case of contracted care) \\
\hline Hospital & Free choice & Selective & Selective \\
\hline Travel distance (min.) & Free choice & $\begin{array}{l}\text { Contracted care within } 30 \\
\text { minutes }\end{array}$ & $\begin{array}{l}\text { Contracted care within } 45 \\
\text { minutes }\end{array}$ \\
\hline Availability of CQI & Very good & Good & Sufficient \\
\hline
\end{tabular}


and research tools. The questionnaire was spread out mostly by e-mail and social media campaigning. The online environment is genuinely equal for every respondent.

This enhances the reliability of the research. Respondents were able to participate at any given time during the period of Tuesday $21^{\text {st }}$ of April until Sunday $26^{\text {th }}$ of April 2015. In total 115 respondents participated. Sixteen respondents were excluded due to missing data.

So, finally 99 respondents were included in our study. Logistic regression analysis was performed using SPSS Statistics version 21 . The probability chance was set on $\mathrm{p}<0.10$.

\section{Results}

\subsection{Respondents}

Table 2 provides the characteristics of the participating respondents. It shows that the sample is fairly representative for the Dutch population although younger and better educated consumers are somewhat more represented in the sample.

\subsection{Analysis}

The results of the logistic regression showing the effect of the demand-side factors are presented in Table 3. The outcomes will be discussed in order of appearance in this table. According to the method of analysis, the B-coefficients represent the effect on the logit for a choice in the discrete choice experiment (thus A or B, A or $\mathrm{C}$ and $\mathrm{B}$ or $\mathrm{C}$ ). The magnitude of the effect corresponds with the measurement of the B-coefficient: the greater the number, the greater the effect.

A positive effect is shown with a positive number, vice verse. The more luxurious/more extensive health plan is assigned as the reference group in the analysis. A positive effect therefore implies a greater chance of choosing the reference category.

Table 3 shows that age has a positive effect in all choices. This means that when the age of a respondent increases, the chance for him or her opting for the more extensive health policy increases.

Age, however, has only a significant, positive effect in the first choice (A or B). It means that with each year the respondent ages, the chance for choosing option A (more luxurious/more extensive health plan) increases with 0.049 .

In addition, the data of the logistic regression shows mixed results for the variable "health status". In the last choice (B versus $\mathrm{C}$ ) the significant effect is quite strong and positive. With an increase of 1 point on the 10-point scale for perceived health, the logit for health policy B (more extensive than policy C) increases with 0.443 . This effect shows a clear demarcation between the policies. Option A (most extensive) turns out to be less attractive for healthy people, but when option B and C are presented respondents will prefer option B (extensive health plan) over C (simple health plan).

Table 4 shows the effects of the supply and context factors.

Table 2. Characteristics of the respondents $(n=99)$.

\begin{tabular}{|c|c|c|c|c|}
\hline Variable & & Frequency & Total & $\%$ \\
\hline Gender & $\begin{array}{c}\text { Males } \\
\text { Females }\end{array}$ & $\begin{array}{l}45 \\
54\end{array}$ & 99 & $\begin{array}{l}45.5 \% \\
54.5 \%\end{array}$ \\
\hline Age & $\begin{array}{l}<25 \text { years old } \\
26-49 \text { years old } \\
>50 \text { years old }\end{array}$ & $\begin{array}{l}59 \\
19 \\
21\end{array}$ & 99 & $\begin{array}{l}59.6 \% \\
19.2 \% \\
21.2 \%\end{array}$ \\
\hline $\begin{array}{l}\text { Health status } \\
\text { (scale from 1: worst to 10: best) }\end{array}$ & $\begin{array}{c}1-7 \\
8-10\end{array}$ & $\begin{array}{l}29 \\
70\end{array}$ & 99 & $\begin{array}{l}29.3 \% \\
70.7 \%\end{array}$ \\
\hline Education & $\begin{array}{l}\text { Intermediate vocational education } \\
\text { Higher vocational education } \\
\text { Science education or higher }\end{array}$ & $\begin{array}{l}55 \\
19 \\
25\end{array}$ & 99 & $\begin{array}{l}55.6 \% \\
19.2 \% \\
25.3 \%\end{array}$ \\
\hline Income & $\begin{array}{c}<€ 20 \mathrm{k} / \text { year } \\
€ 20-€ 40 \mathrm{k} / \text { year } \\
>€ 40 \mathrm{k} / \text { year }\end{array}$ & $\begin{array}{l}66 \\
17 \\
16\end{array}$ & 99 & $\begin{array}{l}66.7 \% \\
17.2 \% \\
16.2 \%\end{array}$ \\
\hline
\end{tabular}


Table 3. Parameters of the logistic regression for logit for various choices*.

\begin{tabular}{ccccccc}
\hline & \multicolumn{2}{c}{ Choice A versus B } & \multicolumn{2}{c}{ Choice A versus C } & \multicolumn{2}{c|}{ Choice B versus C } \\
\hline Variable & B-Coefficient (sig.) & s.e. & B-Coefficient (sig.) & s.e. & B-Coefficient (sig.) & s.e. \\
\hline Constant & $0.244(0.914)$ & 2.274 & $0.366(0.901)$ & 2.924 & $-1.913(0.482)$ & 2.723 \\
Gender & $0.291(0.543)$ & 0.479 & $0.208(0.727)$ & 0.596 & $-0.212(0.729)$ & 0.612 \\
Health status & $-0.115(0.614)$ & 0.228 & $-0.087(0.768)$ & 0.295 & $0.443^{*}(0.099)$ & 0.270 \\
Income & $-0.410(0.639)$ & 0.513 & $-0.204(0.777)$ & 0.720 & $-0.765(0.171)$ & 0.558 \\
Age & $0.049^{*}(0.098)$ & 0.029 & $0.048(0.238)$ & 0.041 & $0.036(0.212)$ & 0.028 \\
Education & $0.185(0.544)$ & 0.304 & $0.405(0.321)$ & 0.408 & $0.322(0.439)$ & 0.416 \\
Nagelkerke pseudo R ${ }^{2}$ & & & & & & 0.095 \\
\end{tabular}

${ }^{*}(\mathrm{p}<0.10),{ }^{* *}$ Sig. = significance.

Table 4. Parameters of the logistic regression for supply and context factors.

\begin{tabular}{|c|c|c|}
\hline Attribute & Coefficient & Significance. \\
\hline Premium costs & -0.029 & $0.092^{*}$ \\
\hline Deductible & -0.011 & 0.125 \\
\hline \multicolumn{3}{|l|}{ Hospital choice } \\
\hline \multicolumn{3}{|l|}{ Free choice } \\
\hline $\begin{array}{c}\text { Selective } \\
\text { healthcare within } \\
<30 \text { min. travel } \\
\text { distance }\end{array}$ & 0.391 & $0.017^{* *}$ \\
\hline $\begin{array}{c}\text { Selective } \\
\text { healthcare within } \\
<45 \text { min. travel } \\
\text { distance }\end{array}$ & -0.276 & $0.089^{*}$ \\
\hline \multicolumn{3}{|l|}{ Availability of CQI } \\
\hline \multicolumn{3}{|l|}{ Sufficient } \\
\hline Good & 0.238 & $0.047^{* *}$ \\
\hline Very good & 0.433 & $0.000^{* * *}$ \\
\hline
\end{tabular}

${ }^{*} \mathrm{p}<0.10,{ }^{* *} \mathrm{p}<0.05, \stackrel{* * *}{\mathrm{p}}<0.01$.

Selective contracting shows two significant results. First, a health plan with selective healthcare within 30 minutes travel distance shows a significant positive effect (when compared to the reference category, i.e. free choice). This means that people are willing to choose for selective healthcare within 30 minutes travel distance over a health plan with free choice. However, this effect disappears completely when the contracted health care provider is at a larger distance. A health plan with contracted healthcare within 45 minutes travel distance shows a significant negative effect (when compared to the reference category, i.e. free choice). Respondents are clearly willing to travel up to 30 minutes, but this seems to be a limit.

The effect of the CQI is positive and increases. There is a significant effect for both categories (good and very good). This means that the attractiveness increases with the quality of the CQI. The premium costs show a slight negative, but significant effect. When the premium costs increase, the attractiveness decreases as was expected. Finally, the effect of the deductible is negative. There is only a tendency that with increasing costs of the deductible, the attractiveness decreases. The effect is not significant.

\section{Conclusions}

Every empirical study involves limitations as does this study [19]. Caution with respect to results is usually warranted. Some caution with our results is needed. The sample does not completely represent the Dutch consumer population, since younger and higher educated people are somewhat over-represented in this study. Nev- 
ertheless, data collection via a self-administered questionnaire is assumed to have resulted in less bias. The risk of social desirability is reduced by the utilization of this type of self-administered questionnaire compared to face-to-face interviews.

This study shows that the deductible as choice-influencing instrument has less influence as age increases. The proclaimed cost savings of this deductible might be lower than expected.

Generally, it can be concluded that healthier people are less likely to choose the extensive health plan. However, this effect reverses when the most extensive and less extensive are presented to the participants. The results thus show a clear demarcation in the preferences of consumers.

A similar demarcation has also been found in the data concerning travel distance. When contracted care is within 30 minutes, this health plan is preferred over the more extensive and expensive one. However, this study also shows that this effect reverses when the travel distance increases to 45 minutes. Consumers in this situation are reluctant to choose selective care and choose for the extensive and expensive option.

Premium costs have a negative effect. A health plan becomes less attractive when the price increases [14]. In addition, an increase in the availability of CQI makes a health plan more attractive.

It can be concluded from this study that the deductible as choice-influencing instrument seems to work for young and healthy people, provided that they do not have to travel more that 30 minutes.

It should be borne in mind that the responses to the cases reflect what the respondents say they would do and may not necessarily reflect what they would do in reality. Prospective studies would be carried out to examine the actual course of action taken by the respondents regarding a differentiated deductible [20].

\section{References}

[1] Van der Geest, S. and Varkevisser, M. (2010) Keuzebeïnvloeding via eigen risico werkt, maar kan beter. TPEdigitaal, 4, 34-48

[2] Centraal Bureau Statistiek (2014) Laagste groei zorguitgaven laatste 15 jaar. https://www.cbs.nl/nl-nl/nieuws/2014/20/laagste-groei-zorguitgaven-in-15-jaar

[3] Van Ewijk, C., van der Horst, A. and Besseling, P. (2013) Gezondheid loont. Tussen keuze en solariditeit. Toekomst voor de zorg. Centraal Planbureau, Den Haag.

[4] Wijnmalen, M. (2012) Het keuzegedrag van verzekerden: de invloed van selectief contracteren op de keuze voor een zorgverzekeraar. Erasmus Universiteit, Rotterdam.

[5] Van der Geest, L. and Heuts, L. (2008) Van later zorg? Financiering van de zorg op lange termijn. NYFER, Breukelen.

[6] Rosenau, P. and Lako, C.J. (2008) An Experiment with Regulated Competition and Individual Mandates for Universal Health Care: The New Dutch Health Insurance System. Journal of Health Politics Policy and Law, 33, 1031-1055. http://dx.doi.org/10.1215/03616878-2008-033

[7] Tiebout, C. (1956) A Pure Theory of Local Expenditures. Journal of Political Economy, 64, 416-424. http://dx.doi.org/10.1086/257839

[8] Anderson, J.G. and Bartkus, D.E. (1973) Choice of Medical Care: A Behavioral Model of Health and Illness Behavior. Journal of Health and Social Behavior, 14, 348-362. http://dx.doi.org/10.2307/2136779

[9] Gabel, J. and Ermann, D. (1985) Preferred Provider Organizations: Performance, Problems, and Promise. Health Affairs, 4, 24-40. http://dx.doi.org/10.1377/hlthaff.4.1.24

[10] Howard, D.H. (2005) Quality and Consumer Choice in Healthcare: Evidence from Kidney Transplantation. The BE Journal of Economic Analysis \& Policy, 5,.

[11] Miller, R.H. and Luft, H.S. (1997) Does Managed Care Lead to Better or Worse Quality of Care? Health Affairs, 16, 7-25. http://dx.doi.org/10.1377/hlthaff.16.5.7

[12] Schut, F.T. and van de Ven, W.P.M.M. (2011) Effects of Purchaser Competition in the Dutch Health System: Is the Glass Half Full or Half Empty? Health Economics, Policy and Law, 6, 109-123.

[13] Vektis (2015) Zorgthermometer. http://www.vektis.nl/downloads/Publicaties/2015/Zorgthermometer\%20nr14/

[14] Abraham, J.M., Feldman, R., Carlin, C. and Christianson, J. (2006) The Effect of Quality Information on Consumer Health Plan Switching: Evidence from the Buyers Health Care Action Group. Journal of Health Economics, 25, 762781. http://dx.doi.org/10.1016/j.jhealeco.2005.11.004

[15] Boonen, L., Laske-Aldershof, T. and Schut, E. (2009) Het effect van CQ informatie op de keuze voor een zorgverzekeraar. http://www.narcis.nl/publication/RecordID/oai\%3Arepub.eur.nl\%3A20171 
[16] van Beest, F., Lako, C.J. and Sent, E.M. (2012) Health Insurance and Switching Behavior: Evidence from the Netherlands. Health, 4, 811-820. http://dx.doi.org/10.4236/health.2012.410125

[17] Kuenen, J.W., Geurts, M., Leeuwen, W.V. and Nolst Trenité, T. (2010) Kiezen voor kwaliteit. Portfoliokeuzes van ziekenhuizen zorgen voor hogere kwaliteit en lagere kosten. Boston Consulting Group. http://www.bcg.nl/documents/file65689.pdf

[18] Johnson, F.R., Lancsar, E., Marshall, D., Kilambi, V., Mühlbacher, A., Regier, D.A. and Bridges, J.F. (2013) Constructing Experimental Designs for Discrete-Choice Experiments: Report of the ISPOR Conjoint Analysis Experimental Design Good Research Practices Task Force. Value in Health, 16, 3-13. http://dx.doi.org/10.1016/j.jval.2012.08.2223

[19] Lako, C.J. and Rosenau, P. (2009) Dutch Health Policy toward Demand-Driven Care; Results from a Survey into Hospital Choice. Health Care Analysis, 17, 20-35.

[20] Lako, C.J., Huygen F.J.A., Lindenthal J.J. and Persoon, J.M.G.(1990) Handling of Confidentiality in General Practice. A Survey among 272 General Practitioners in the Netherlands. Family Practice, 7, 34-38. 